\title{
The VGF-derived peptide TLQP-62 modulates insulin secretion and glucose homeostasis
}

\author{
Pamela Petrocchi-Passeri ${ }^{1,2}$, Cheryl Cero ${ }^{3}$, Alessandro Cutarelli ${ }^{1,4}$, Claudio Frank ${ }^{4}$, \\ Cinzia Severini ${ }^{2,5}$, Alessandro Bartolomucci ${ }^{3}$ and Roberta Possenti, ${ }^{1,2}$ \\ ${ }^{1}$ Department of Medicine of Systems, University of Rome Tor Vergata, Via Montpellier, 100133 Rome, Italy \\ ${ }^{2}$ Institute of Cell Biology and Neurobiology, CNR, Rome, Italy \\ ${ }^{3}$ Department of Integrative Biology and Physiology, University of Minnesota, Minneapolis, Minnesota, USA \\ ${ }^{4}$ Istituto Superiore di Sanità, Rome, Italy \\ ${ }^{5}$ EBRI Foundation, Rome, Italy
}

\author{
Correspondence \\ should be addressed \\ to R Possenti \\ Email \\ roberta.possenti@gmail.com
}

\begin{abstract}
Insulin secretion control is critical for glucose homeostasis. Paracrine and autocrine

molecules secreted by cells of the islet of Langerhans, as well as by intramural and autonomic neurons, control the release of different hormones that modulate insulin secretion. In pancreatic islets, the abundant presence of the granin protein VGF (nonacronymic; unrelated to VEGF) suggests that some of its proteolytically derived peptides could modulate hormone release. Thus, in the present study, we screened several VGF-derived peptides for their ability to induce insulin secretion, and we identified the VGF C-terminal peptide TLQP62 as the most effective fragment. TLQP-62 induced a potent increase in basal insulin secretion as well as in glucose-stimulated insulin secretion in several insulinoma cell lines. We found that this peptide stimulated insulin release via increased intracellular calcium mobilization and fast expression of the insulin 1 gene. Moreover, the peripheral injection of TLQP-62 in mice improved glucose tolerance. Together, the present findings suggest that TLQP-62, acting as an endocrine, paracrine, or autocrine factor, can be considered a new, strong insulinotropic peptide that can be targeted for innovative antidiabetic drug discovery programs.
\end{abstract}

Key Words

- neuropeptide

- intracellular calcium

- signaling

- GSIS

diabetes

Journal of Molecular

Endocrinology

(2015) 54, 227-239

\section{Introduction}

Impaired insulin secretion and insulin resistance play major roles in the development of type 2 diabetes (T2D). The most important regulators of insulin secretion are plasma nutrients, among which glucose is the most effective; however, peripherally and locally secreted hormones, neurotransmitters, and many neuropeptides of the autonomic nervous system and intramural pancreatic ganglia also strongly affect insulin release (Braun et al. 2012). Understanding the complex mechanisms of insulin secretion is a main goal of identifying new drugs that are able to prevent and/or ameliorate the negative metabolic aspects of T2D.

The $V g f$ (nonacronymic) gene has been identified as a nerve growth factor target gene (Levi et al. 1985, Salton et al. 1991). The VGF protein has biochemical features of the granin family of pro-peptide precursors (Helle 2004, Bartolomucci et al. 2011). VGF-derived peptides play an important role in metabolic homeostasis, insofar as they

Published by Bioscientifica Ltd 
balance feeding behavior and energy expenditure: germline deletion of the $V g f$ gene resulted in a hypermetabolic, lean, and obesity-resistant phenotype in mice (Hahm et al. 1999, 2002, Watson et al. 2005, 2009). Notably, $V g f$ knockout mice became sensitive to insulin and resistant to developing hyperinsulinemia when they were placed on a high-calorie diet or when they were crossed with different diabetes/obese mouse models (Watson et al. 2005).

VGF is a precursor molecule that is processed into an array of various peptides stored in large, dense core granules and secreted via the regulated secretory pathway in response to different stimuli, such as membrane depolarization and intracellular signaling activation (Possenti et al. 1989, 1999, Trani et al. 1995, 2002, Severini et al. 2009, Ferri et al. 2011). At least seven peptides have been shown to possess non-redundant biological functions in rodents, and VGF fragments are increasingly being recognized as useful biomarkers for human diseases (Bartolomucci et al. 2011). VGF is expressed and the peptides are stored in $\beta$ cells (Possenti et al. 1989) and other cell types of the islet of Langerhans as well as in intramural fibers and ganglia of the pancreas (Cocco et al. 2007).

The C-terminal internal fragment TLQP-21 - which was originally investigated for its role in energy balance and lipolysis (Bartolomucci et al. 2006, 2009, Fargali et al . 2012, Possenti et al. 2012) - has recently been implicated in glucose homeostasis (Stephens et al. 2012). TLQP-21 has been shown to modulate glucose-stimulated insulin secretion (GSIS) and glucose homeostasis and to protect $\beta$ cells from degeneration in rats (Stephens et al. 2012). Indeed, TLQP-21 has been shown to be released from the islets of Langerhans, which suggests that it works through a paracrine or autocrine mechanism (Stephens et al. 2012). Another VGF-derived peptide, NERP-2, has been reported to enhance GSIS in the mouse pancreatic $\beta$ cell line MIN6 and isolated pancreatic islets (Moin et al. 2012). Because we have previously shown that primary neuronal cell cultures (Trani et al. 2002) and tumor-derived $\beta$ cell lines (Possenti et al. 1999) contain and secrete the C-terminal VGF peptides upon depolarization stimuli, in the present study, we aimed to analyze their ability to modulate insulin secretion. We found that the C-terminal fragment TLQP-62 - which was previously identified in the CNS (Trani et al. 1995, Bartolomucci et al. 2006) and showing activity on synaptic plasticity (Alder et al. 2003, Bozdagi et al. 2008, Thakker-Varia et al. 2014) - was the most potent in inducing insulin secretion and in improving glucose tolerance in vivo.

\section{Materials and methods}

\section{Materials}

Media and serum were purchased from EuroClone (Paignton, Devon, UK); antibodies were raised against VGF by our group (Ferri et al. 2011); antibodies against phosphorylated protein kinases were purchased from Cell Signaling Technology (Danvers, MA, USA); all of the other chemicals, where not specified, were purchased from Sigma-Aldrich.

TLQP-62 was synthesized at the BioMedical Genomics Center, University of Minnesota (Minneapolis, MN, USA). All of the other peptides used were purchased from PRIMM Srl (Milan, Italy). See Supplementary Figure 1 for amino acid sequences (see section on supplementary data given at the end of this article) (NM_030997.1). We also used two different scrambled peptides that had the amino acid content of TLQP-21 (Petrocchi Passeri et al. 2013) and LQEQ-19.

\section{Cell cultures}

The rat INS1 and INS1E cell lines were kindly provided by Prof. C Wollheim and Dr P Maechler (Rubì et al. 2002). MIN6B1 cells (Lilla et al. 2003) were provided by Dr P Halban (University of Geneva, Switzerland), with permission from Dr J-I Miyazaki (University of Osaka, Japan), who produced the maternal MIN6 cell line (Miyazaki et al. 1990). $\beta$ TC6 cells were originally obtained from Dr S Efrat (Efrat et al. 1988).

INS1 and INS1E cells were cultured in RPMI 1640 supplemented with $5 \%$ fetal bovine serum (FBS), $10 \mathrm{mM}$ HEPES, $1 \mathrm{mM}$ sodium pyruvate, $2 \mathrm{mM}$ L-glutamine, $100 \mathrm{units} / \mathrm{ml}$ penicillin, $100 \mu \mathrm{g} / \mathrm{ml}$ streptomycin, and $50 \mu \mathrm{M}$ 2-mercaptoethanol. INS1E cells were cultured between passages 87 and 100 and were grown at $37^{\circ} \mathrm{C}$ under $95 \%$ humidified air: $5 \% \mathrm{CO}_{2}$. $\beta$ TC6 cells were cultured in DMEM containing 15\% FBS and 25 mM HEPES. MIN6B1 cells were maintained in DMEM containing $25 \mathrm{mM}$ glucose, $15 \% \mathrm{FBS}$, and $70 \mu \mathrm{M} \beta$-mercaptoethanol. For experiments, cells were cultured on poly-L-lysine-coated 96 -well plates or in $35 \mathrm{~mm}$ dishes and maintained at $37{ }^{\circ} \mathrm{C}$ under $5 \% \mathrm{CO}_{2}$. Cells grown on glass cover slides were used for immunofluorescence studies.

\section{Western blotting}

Cells were harvested in lysis buffer ( $20 \mathrm{mM}$ Tris- $\mathrm{HCl}, 0.5 \%$ $\mathrm{NP} 40$, and $10 \mathrm{mM}$ EDTA in the presence of protease

Published by Bioscientifica Ltd 
inhibitors). Equivalent amounts of cell extracts (1/10 of the plate, $\sim 1 \times 10^{5}$ cells) were mixed with sample buffer according to Invitrogen NuPAGE. Following heating at $70{ }^{\circ} \mathrm{C}$ for $10 \mathrm{~min}$, proteins were subjected to Nu-PAGE 4-12\% Bis-Tris gels and then transferred electrophoretically to a PVDF membrane (Amersham, GE Healthcare, Little Chalfont, Buckinghamshire, UK). After staining with Ponceau $\mathrm{S}$ to verify the uniformity of protein load/transfer, the membranes were blocked with 5\% low-fat milk in buffer for $2 \mathrm{~h}$ at room temperature and then analyzed for immunoreactivity. Incubation with primary rabbit C-terminal VGF antibodies (1:5000) was performed overnight at $4{ }^{\circ} \mathrm{C}$. Incubation with peroxidase-coupled secondary goat-anti-rabbit antibodies (1:20 000, SigmaAldrich) was performed at room temperature for $1 \mathrm{~h}$ and developed with ECL system (GE Healthcare).

\section{Immunofluorescence}

Insulinoma cells were fixed with $4 \%$ paraformaldehyde (w/v in PBS) for $15 \mathrm{~min}$ at room temperature. Fixed cells were permeabilized with $0.2 \%$ Triton $\mathrm{X}-100$ in Tris-HCl $(\mathrm{pH}$ 7.4) for $5 \mathrm{~min}$, then incubated with the rabbit polyclonal antibody against the C-terminal sequence of VGF (1:2000) at room temperature for $2 \mathrm{~h}$ in a humidified chamber. TRITC-conjugated secondary antibodies (1:2000, Sigma-Aldrich) were incubated for $30 \mathrm{~min}$ at room temperature. Confocal microscopy was performed with a Leica TCS 4D system (Leica Biosystems, Nussloch, Germany) equipped with a $100 \times 1.3-0.6$ oil immersion objective.

\section{TLQP-21 EIA}

Material secreted into the extracellular culture milieu was precipitated with trichloro acetic acid (TCA) and resuspendend in EIA buffer according to the manufacturer's protocol (TLQP-21 ELISA Kit; EK-003-89, Phoenix Pharmaceuticals, Burlingame, CA, USA). Briefly, $50 \mu \mathrm{l}$ of media, rehydrated primary antibody, and biotinylated TLQP-21 were loaded onto a pre-coated secondary antibody plate. Each sample was tested in duplicate. Following incubation and several washes, streptavidinHRP was added and incubated for $1 \mathrm{~h}$ with orbital shaking to detect bound secondary antibody. After washing and blocking the reaction with $2 \mathrm{M} \mathrm{HCl}$, the ELISA reaction was measured at $450 \mathrm{OD}$ on a microplate reader (1420 Multilabel Counter, VICTOR 3, PerkinElmer, Waltham, MA, USA).

\section{Insulin secretion}

Insulin concentrations were measured using an ELISA kit specific for rat/mouse insulin (Millipore Corporation, Billerica, MA, USA). The cells were washed four times with a glucose-free buffer in modified Krebs-Ringerbicarbonate-HEPES buffer (KRBH buffer: $134 \mathrm{mM} \mathrm{NaCl}$, $4.7 \mathrm{mM} \mathrm{KH}{ }_{2} \mathrm{PO} 4,1.4 \mathrm{mM} \mathrm{MgSO} 4,1 \mathrm{mM} \mathrm{CaCl} 2$, and $10 \mathrm{mM}$ HEPES (pH 7.4)) without BSA. Fresh KRBH containing the different VGF-derived peptides (TLQP-62, AQEE-30, or TLQP-21 at concentrations of 1, 3, and $10 \mu \mathrm{M}), 10 \mu \mathrm{M}$ forskolin (Frsk), $1 \mathrm{mM}$ dibutyryl-cAMP (dbcAMP), glucose at either a low $(2.5 \mathrm{mM})$ or high $(20 \mathrm{mM})$ concentration, $100 \mathrm{nM}$ tetra phorbol myristate (TPA), or $56 \mathrm{mM} \mathrm{KCl}$ were applied, and the supernatants were collected after $1 \mathrm{~h}$ of stimulation. Thereafter, the supernatant was centrifuged at $1200 \boldsymbol{g}$ for $5 \mathrm{~min}$ in order to pellet the suspended material, and the supernatant was utilized for insulin ELISA and for 15\% TCA precipitation according to the manufacturer's instructions.

To verify the integrity of the cells, we performed western blotting on TCA-precipitated supernatants to confirm the presence of actin or tubulin in the medium. We eliminated the samples that contained these proteins, which indicated the presence of cell lysis or secretory bodies such as exosomes. Preliminary experiments led us to be confident that no lysis was present with up to $3 \mathrm{~h}$ of secretion stimulation under standard conditions.

\section{RNA purification, RT, and gene expression evaluation by real-time PCR}

Total RNA was extracted using TRIzol (Invitrogen), according to the manufacturer's instructions. RNA yield and purity were determined by spectrophotometry absorption at 260 and $280 \mathrm{~nm}$. To obtain cDNA, $2 \mu \mathrm{g}$ total RNA was reverse transcribed in MLV RT buffer (Promega), $1 \mathrm{mM}$ dNTP, $40 \mathrm{U} / \mathrm{ml}$ of Recombinant RNasin Ribonuclease Inhibitor (Promega), and MLV reverse transcriptase (Promega) in a final volume of $25 \mu \mathrm{l}$. The reaction was incubated at $37^{\circ} \mathrm{C}$ for $60 \mathrm{~min}$, and the resulting cDNA was stored at $-20^{\circ} \mathrm{C}$ until it was used for analysis. Relative mRNA expression was measured with quantitative real-time PCR (qPCR) using the 7900HT Fast Real-Time PCR System (Applied Biosystems, Austin, TX, USA); SYBR Select Master Mix fluorescence (Applied Biosystems) was used to quantify the relative amplicon amount. Cycle time $(C t)$ values for all of the samples were normalized with Tata Binding Protein (TBP; Invitrogen) using the $\Delta \Delta C t$ formula. Each cDNA sample from treated

Published by Bioscientifica Ltd 
cells was assayed in triplicate for each point. For each set of primers, a no-template control and a no-reverse transcriptase control were included. The thermal cycling conditions were: denaturation at $95^{\circ} \mathrm{C}$ for $2 \mathrm{~min}$, followed by 40 cycles at $95^{\circ} \mathrm{C}$ for $15 \mathrm{~s}$ and at $60^{\circ} \mathrm{C}$ for $1 \mathrm{~min}$. Post-amplification dissociation curves were performed to verify the presence of a single amplification product and the absence of genomic DNA contamination.

The primer sequences used in the present study were as follows for rat genes: $V g f$ (GenBank NM_030997.1) forward: 5'-AGACGGGTCCGGATTTTC-3', reverse: 3'-CAGAAGAGGACGGATGCTG-5'; Ins1 (GenBank NM_019129.3) forward: 5'-AGACCATCAGCAAGCAGGTC-3', reverse: 3'-CTTGGCTCCCAGAGGAC-5'; Ins2 (GenBank NM 019130.2) forward: 5'-CGAAGTGGAGGACCCACA-3', reverse: 3'-TGCTGGTGCAGCACTGAT-5'; Tbp (GenBank NM_001185084.1) forward: 5'-CAGGTGGCAGCATGAAGTGAC-3', reverse: 5'-AAGTAGCAGCACAGAGCAAGC-3'.

For mice genes, the sequences were: $V g f$ (GenBank NM_001039385.1) forward: 5'-CGACCCTCCTCTCCACCT-3', reverse: 5'-CCCAACCCCTGGATCAGTA-3'; Ins1 (GenBank NM_008386.3) forward: 5'-CAGAGAGGAGGTACTTTGGACTATAAA-3', reverse: 5'-GCCATGTTGAAACAATGACCT-3'; Ins2 (GenBank NM_001185084.1) forward: 5'-GCCCTAAGTGATCCGCTACA-3', reverse: 5'-GCCATGTTGAAACAATAACCTG-3'; Tbp (GenBank NM_001185084.1) forward: 5'-CCAATGACTCCTATGACCCCTA-3', reverse: 5'-CAGCCAAGATTCACGGTAGAT-3

\section{Signaling}

INS1 cells were plated $\left(10 \times 10^{5}\right)$ on $35 \mathrm{~mm}$ poly-L-lysinetreated culture dishes and cultured overnight in complete medium. We assessed kinase activation as previously described (Petrocchi et al. 2010). Briefly, cells were starved for $1 \mathrm{~h}$ in serum-free RPMI with HEPES, sodium pyruvate, $\beta$-mercaptoethanol, and the substances to be tested, and incubated at $37{ }^{\circ} \mathrm{C}$ under $5 \% \mathrm{CO}_{2}$. At the end of the incubation period, the reaction was quickly stopped with ice by removing the medium and adding cold lysis buffer (50 mM Tris- $\mathrm{HCl}$ (pH 7.5), $150 \mathrm{mM} \mathrm{NaCl}, 10 \mathrm{mM}$ EDTA) in the presence of a phosphatase and protease inhibitor mixture (Sigma-Aldrich). Harvested cells were kept at $-80^{\circ} \mathrm{C}$ until they were gel-run.

For each experiment, equivalent amounts of cell extracts (one-quarter of the plate, which was equivalent to $\sim 5 \times 10^{5}$ cells) were run as described in the western blot section. Membranes were incubated overnight at $4{ }^{\circ} \mathrm{C}$ with the specific primary antibodies - anti-pPKC, anti-pAMPK, or anti-p-Erk1/2 (1:1000; Cell Signaling Technology) - in $5 \%$ BSA Tris buffer saline plus $1 \%$ Tween 20 (the following were also tested: anti-p-AKT, anti-p-P38, anti-p-JNK, antip-PKA substrate, anti-p-PKD substrate, anti-p-PLC, and anti-p-PLA). Then, cells were incubated for $1 \mathrm{~h}$ at room temperature with secondary goat-anti-rabbit peroxidaseconjugated antibodies (1:5000, GE Healthcare) in 5\% BSA Tris buffer saline plus 1\% Tween 20. After extensively washing the membranes, band detection was carried out by the ECL system (GE Healthcare). To normalize for sample loading, the blots were stripped (Restore Western Blot Stripping, Thermo Scientific, Rockford, IL, USA) and reprobed with an antibody against $\alpha$-tubulin or $\beta$-actin (1/10 000; Sigma-Aldrich) overnight at $4{ }^{\circ} \mathrm{C}$ and used as internal controls. Blots were analyzed by scanning densitometry and quantified using ImageJ Software (NIH, Bethesda, MA, USA).

To investigate receptor identity, the $\mathrm{C} 3 \mathrm{a}$ peptide agonist C3a70-77 (Anaspec, Fremont, CA, USA) and the C3a receptor antagonist SB290157 (Calbiochem, San Diego, CA, USA) were used.

\section{Analysis of intracellular $\mathrm{Ca}^{2+}$ cycling}

Optical fluorometric recordings with membrane-permeable forms of the calcium indicator Fura2AM (F1221) were used to evaluate intracellular calcium variations. Stock solutions were obtained by adding $50 \mu \mathrm{g}$ of the dye to $50 \mu \mathrm{l}$ of $75 \%$ DMSO plus $25 \%$ pluronic acid (F-127, Molecular Probes, Life Technologies, Carlsbad, CA, USA) and were stored frozen at $-20^{\circ} \mathrm{C}$. Cells plated $48 \mathrm{~h}$ before experiments were bathed for $60 \mathrm{~min}$ at room temperature in $1 \mathrm{ml}$ of extracellular solution (HBSS: $125 \mathrm{mM} \mathrm{NaCl}$, $1 \mathrm{mM} \mathrm{KCl}, 5 \mathrm{mM} \mathrm{CaCl}_{2}, 1 \mathrm{mM} \mathrm{MgCl}_{2}$, and $20 \mathrm{mM}$ HEPES (pH 7.35), with $4.5 \mathrm{mM}$ glucose; EuroClone), with a final Fura2AM concentration of $5 \mu \mathrm{M}$. This solution was then removed and replaced with fresh Ringer solution, and the plates were quickly placed on the microscope stage. When not otherwise specified, Ringer solution with $4.5 \mathrm{mM}$ glucose was used for experiments. The samples were analyzed for a $15-60 \mathrm{~min}$ period during which the ratio between the values of light intensity at 340 and $380 \mathrm{~nm}$ stimulation (F340/380) was recorded every $6 \mathrm{~s}$. The change in intracellular fluorescence intensity, which indicates the cytoplasm-free calcium level $\left(\left[\mathrm{Ca}^{2+}\right]_{\mathrm{i}}\right)$ of cells after treatment with VGF-derived peptides and control substances, was measured by fluorescence microscopy with single-cell records: to measure fluorescence changes, a computerized analysis system was used (ImagEM; Hamamatsu Photonix, Hamamatsu, Japan). After each

Published by Bioscientifica Ltd 
experiment, cells were stimulated with $56 \mathrm{mM} \mathrm{KCl}$ to confirm cell reactivity. Cells that did not respond to the application of $\mathrm{KCl}$ were eliminated from the analysis.

Experiments were performed at least three times, and 35-45 single cells were recorded and averaged per experiment. Data presented in the figures are means \pm S.E.M. of one representative experiment per group.

\section{Cell proliferation assays}

Cells were plated on poly-L-lysine-treated 96-well plates $\left(3 \times 10^{4}\right.$ cells/well $)$ and cultured overnight in complete medium. Medium was then removed, and RPMI containing the test substances was applied to eight wells each. Cells were then cultured for 24 or $48 \mathrm{~h}$. The metabolic activity of the cells was determined by a colorimetric methyl thiazolyl tetrazolium (MTT) assay as previously described (Petrocchi Passeri et al. 2013).

Proliferation was analyzed by BrdU incorporation (Cell Proliferation ELISA BrdU, Roche Diagnostics) according to the manufacturer's instructions. We performed $4 \mathrm{~h}$ of BrdU incorporation after the substance application.

Statistical analysis, which was performed on data from six wells (after eliminating the highest and the lowest points), was based on a paired two-tailed $t$-test between the mean values of the treated cells and the control cells. Experiments were performed in triplicate.

\section{In vivo glucose tolerance test}

Male CD1 mice (Charles River, USA) weighing 25-30 g were acclimatized for 10 days and housed under conventional housing conditions. A glucose tolerance test (GTT) was performed after an overnight fast. Mice were injected i.p. with TLQP-62 (1 or $5 \mathrm{mg} / \mathrm{kg})$ or saline vehicle $30 \mathrm{~min}$ before an i.p. dose of $2 \mathrm{~g} / \mathrm{kg}$ D-glucose (Stephens et al. 2012). Blood glucose levels from tail bleedings were monitored with an Accucheck Aviva glucometer (Roche Diagnostics) at $-30,0,30,60$, and $120 \mathrm{~min}$ from the glucose injection. Protocols were approved by the IACUC, University of Minnesota.

\section{Statistical analysis}

Data are expressed as means \pm s.E.M. and analyzed with unpaired two-tailed $t$-tests between the mean values of the treated cells and the control cells; GTT data were analyzed with ANOVA followed by Tukey's honestly significant difference (HSD) post hoc test. Differences were considered significant at $P<0.05$.

\section{Results}

\section{VGF protein expression in insulinoma cell lines}

We first aimed to confirm the expression of VGF in different $\beta$ cell lines (Possenti et al. 1999, Cocco et al. 2007) that are known to fully process the VGF precursor ( $\sim 70 \mathrm{kDa})$, as well as its smaller fragments, using selective C-terminal antibodies (Ferri et al. 2011). VGF was constitutively expressed in all of the tested cell lines, and its expression became markedly increased after overnight treatment with Frsk (Fig. 1A) or dbcAMP (Possenti et al. 1999). In contrast, TPA, which first activates and then down-regulates PKC (Supplementary Figure 2), only slightly induced VGF protein expression (Fig. 1A). Positive immunostaining for the C-terminal portion (Ferri et al. 2011) in perinuclear (Golgi apparatus) and punctuated peripheral (secretory vesicles) areas confirmed the intragranular localization of VGF for all of the cell lines tested (Fig. 1B).

The observation that cAMP up-regulated VGF processing suggested that VGF could be strongly modulated by incretine peptide signaling via PKA (e.g., glucagon and glucagon peptide-like 1) as well as by neurotransmitters (e.g., norephinephrine).

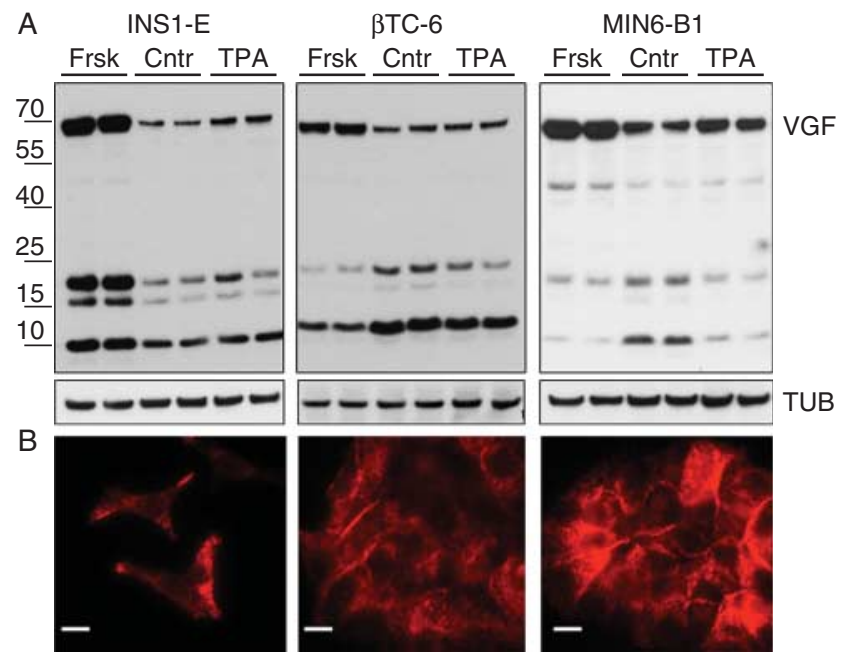

\section{Figure 1}

Expression of VGF and its fragments in the insulinoma cell lines. (A) Representative western blots of the VGF precursor and C-terminal peptides in INS1E, $\beta$ TC-6, and MIN6B1 cells, cultured overnight with $10 \mu \mathrm{M}$ forskolin (Frsk) or $100 \mathrm{nM}$ tetra phorbol myristate (TPA), and control cells (Cntr). Loading controlled with tubulin (TUB). Frsk up-regulated VGF expression more than TPA did. (B) Immunofluorescence analysis revealed that VGF was present in a punctuated pattern characteristic of secretory vesicles in all three cell lines. Scale bars $=5 \mu \mathrm{m}$. A full colour version of this figure is available at http://dx.doi.org/10.1530/JME-14-0313.

Published by Bioscientifica Ltd 
Western blotting and EIA demonstrated that VGFderived peptides were secreted (Supplementary Figure 3). Moreover, we noticed that $3 \mathrm{~h}$ of secretory stimuli could affect cell viability, as demonstrated by the detection of actin in the medium (Supplementary Figure 3). We thus performed all secretory experiments with a $1 \mathrm{~h}$ exposure time.

\section{C-terminal VGF-derived peptides stimulate insulin secretion in insulinoma cells}

After finding that VGF is expressed and smaller fragments are secreted upon increased cAMP, we assessed the insulin secretion activity of three main C-terminal VGF-derived peptides (namely, TLQP-62, AQEE-30, and TLQP-21), several smaller fragments, and scrambled peptides (Supplementary Table 1). To this end, INS1 cells cultured in a low-glucose condition (Jones \& Persaud 1998) were stimulated with the different VGF peptides. We found that TLQP-62 was the most potent insulin secretagogue (Fig. 2A and B), whereas TLQP-21 and AQEE-30 had no, or a weak, effect under this experimental condition. We thus used peptides at a high dose $(10 \mu \mathrm{M})$ for all subsequent experiments to maximize stimulations.

According to previous work (Hohmeier et al. 2000), variations in insulin secretion in the different cell lines are the result of glucose sensitivity either to the voltagedependent calcium channels or to cell confluence. Therefore, we used the INS1E subclone cell line for follow-up experiments because of their higher sensitivity to glucose and peptide stimulation and because of the very low effect that confluence has on them. We found that TLQP62 was a potent insulin secretagogue independently of glucose concentration (Fig. 2C). Conversely, TLQP-21 had only a very weak effect at the low-glucose concentration, but it nevertheless potentiated GSIS, which is consistent with what has been reported previously (Stephens et al. 2012). Moreover, none of the smaller fragments of TLQP62 (TLQP-8, AQEE-10, or YIEH-10) or the scrambled peptides affected the insulin secretion of insulinoma cell lines under either low- or high-glucose conditions (data not shown).

\section{Gene expression regulation by TLQP-62 in INS1E cells}

Modulation of Ins1, Ins2, and Vgf mRNA expression was assessed with time-course experiments for 2, 6, and $18 \mathrm{~h}$ (overnight) (Fig. 3). High glucose slightly but significantly stimulated transcription of Ins 1 and $V g f$ at $2 \mathrm{~h}$ but not at the later time points (Fig. 3A); moreover, it up-regulated
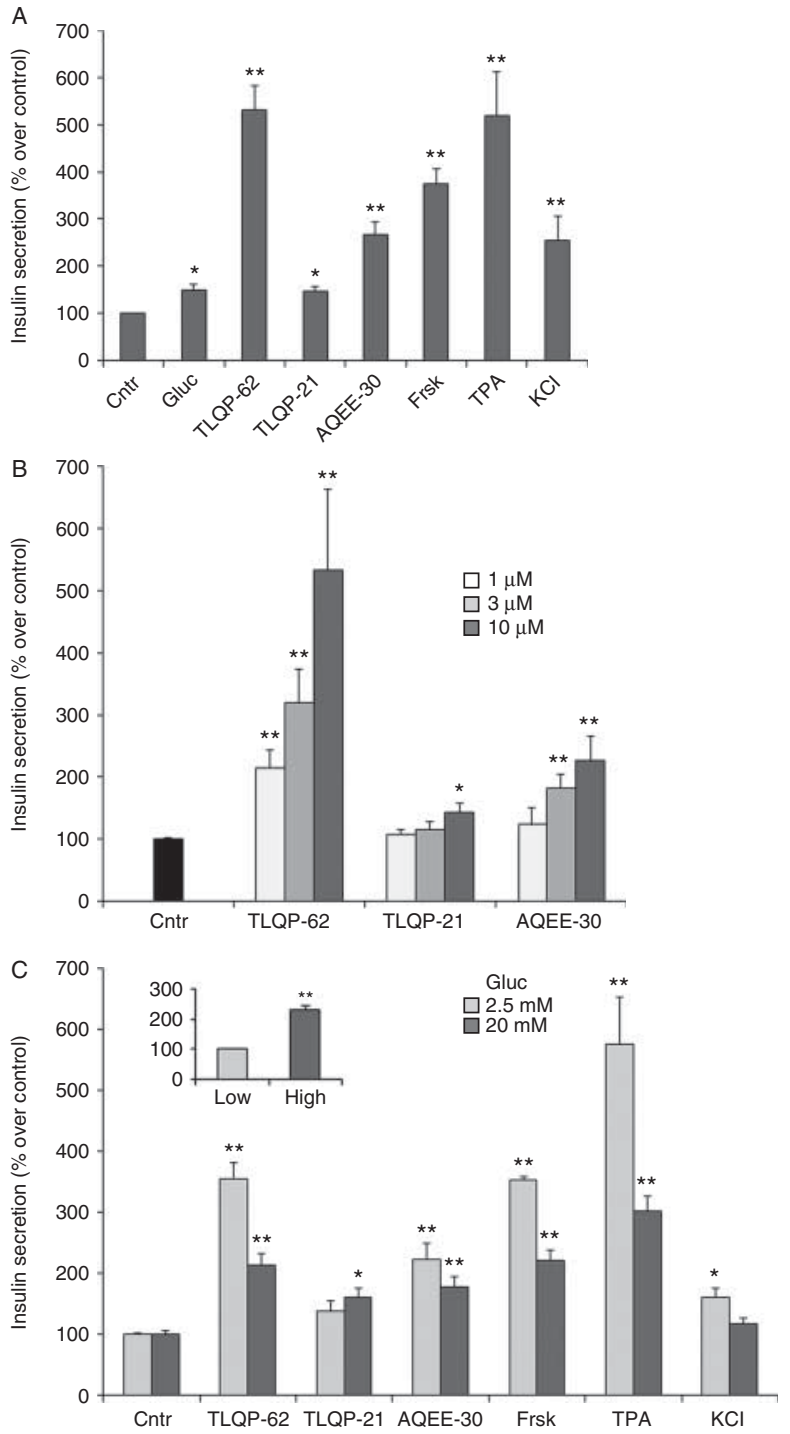

Figure 2

Stimulation of insulin secretion by VGF fragments in insulinoma cells. (A) Insulin secretion was assessed in INS1 cells after $1 \mathrm{~h}$ of static incubation in medium containing a low glucose concentration $(2.5 \mathrm{mM})$ plus $10 \mu \mathrm{M}$ of one of three C-terminal VGF-derived peptides (TLQP-62, TLQP-21, or AQEE30). The positive controls were: Glc, $20 \mathrm{mM}$ glucose; Frsk, $10 \mathrm{mM}$ forskolin; TPA, $100 \mathrm{nM}$ tetra phorbol myristate; and $\mathrm{KCl}, 56 \mathrm{mM}$ potassium chloride. Graph of means \pm s.E.M. of six independent experiments run in duplicate. (B) Insulin secretion by INS1 cells after $1 \mathrm{~h}$ of static incubation in medium containing low glucose $(2.5 \mathrm{mM})$ and different concentrations $(1,3$, or $10 \mu \mathrm{M}$ ) of a C-terminal VGF-derived peptide (TLQP-62, TLQP-21, or AQEE-30). Graph of means \pm s.E.M. of three independent experiments run in duplicate. (C) Insulin secretion by INS1E cells after $1 \mathrm{~h}$ of static incubation in media containing $10 \mu \mathrm{M}$ of a C-terminal VGF-derived peptide (TLQP-62, TLQP-21, or AQEE-30), $10 \mu \mathrm{M}$ Frsk, $100 \mathrm{nM}$ TPA, or $56 \mathrm{mM} \mathrm{KCl}$ in either low $(2.5 \mathrm{mM})$ or high ( $20 \mathrm{mM})$ glucose (Gluc). Insert, the ratio of insulin secretion in INS1Es cell in high glucose $(20 \mathrm{mM})$ to that in low glucose $(2.5 \mathrm{mM})$. Graph of means \pm s.E.M. of six independent experiments run in duplicate. Statistical significance between mean values of treated cells and control cells (Cntr: 100\%) was analyzed using the paired two-tailed $t$-test: $* P<0.01$ and $* * P<0.001$.

Published by Bioscientifica Ltd. 

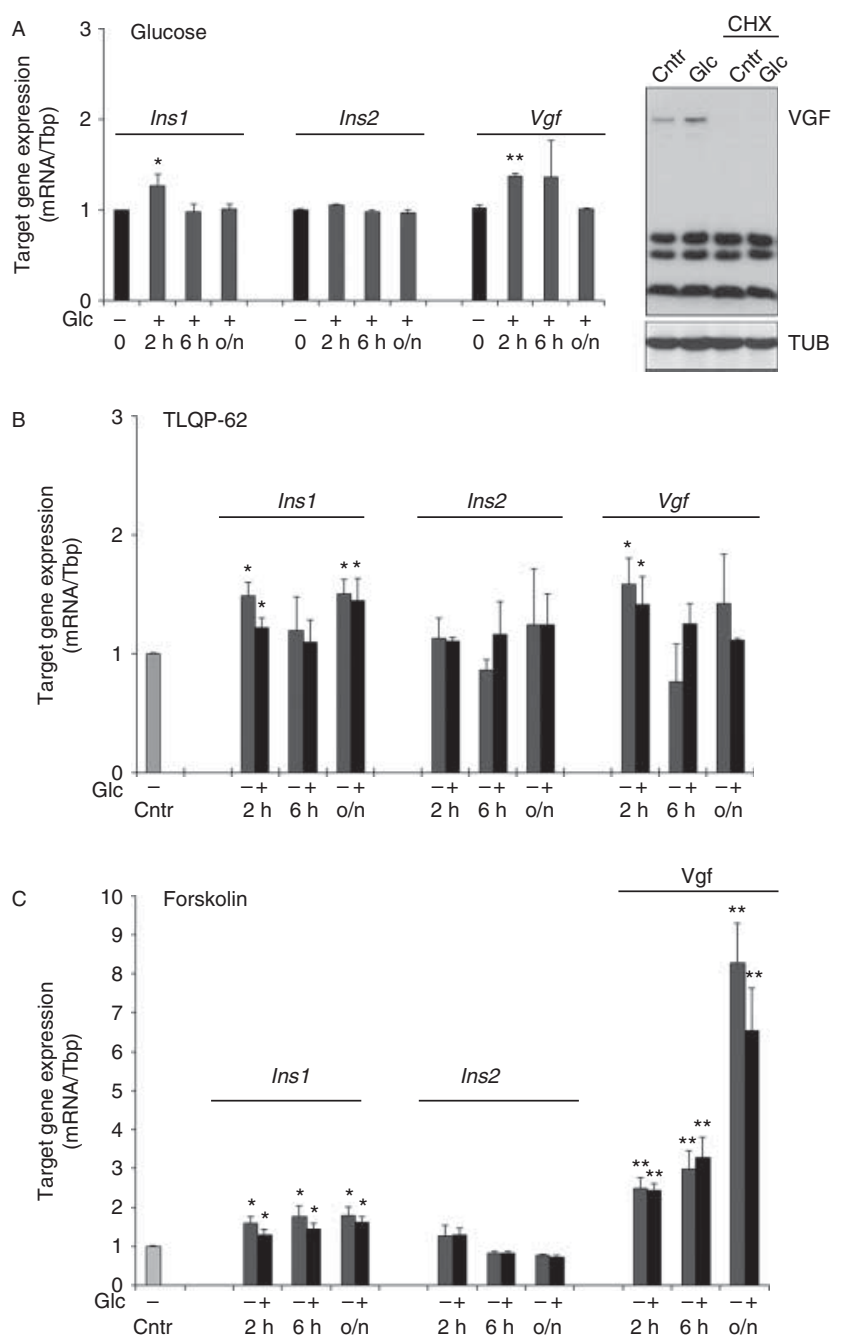

Figure 3

Modulation of insulin and $V g f$ mRNAs by TLQP-62. (A) qPCR for insulin 1 (Ins1), Ins2, and $V g f$ genes after exposure to high glucose (20 mM) for $2 \mathrm{~h}$, $6 \mathrm{~h}$, or $18 \mathrm{~h}(\mathrm{o} / \mathrm{h})$. Insert, western blot demonstrating that the increase in VGF precursor after $2 \mathrm{~h}$ of exposure to high glucose was countered by pretreatment for $15 \mathrm{~min}$ with $20 \mu \mathrm{g} / \mathrm{ml}$ cyclohexamide (CHX). TUB, tubulin. (B) qPCR for Ins1, Ins2, and Vgf after exposure to $10 \mu \mathrm{M}$ TLQP-62. (C) qPCR for Ins1, Ins2, and $V g f$ genes in the presence of $10 \mu \mathrm{M}$ forskolin (Frsk). Statistically significant differences between mean values of treated cells and control cells (Cntr: $100 \%)$ were analyzed using the paired two-tailed $t$-test: $* P<0.05$ and $* * P<0.001$.

expression of the VGF precursor protein (Fig. 3A, inset), an effect blocked by pretreatment with cyclohexamide. This suggested that the effect was transcriptionally dependent, but we also cannot exclude the glucose-mediated translational regulation of mRNAs, which has been previously reported (Melloul et al. 2002). In a similar fashion, TLQP62 increased Ins 1 and $V g f$ gene expression but not that of Ins 2 at $2 \mathrm{~h}$ (Fig. 3B). As expected, Frsk induced transcription of Ins1 (Philippe \& Missotten 1990) and strongly increased $V g f$ mRNA as well (Fig. 3C) (Possenti et al. 1999); moreover, the effect of Frsk was not affected by the glucose concentration in the medium.

\section{Intracellular signaling pathways activated by TLQP-62}

It has been well established that insulin is secreted in response to high glucose, but many other secretogogues can modulate its secretion through the activation of different intracellular signal pathways (Jones \& Persaud 1998). To investigate the signaling activity of TLQP-62 in INS1E cells, we measured its effect on the phosphorylation levels of endogenous protein kinases (Fig. 4). TLQP-62 induced a significant early decrease $(2-5 \mathrm{~min})$ in AMPK phosphorylation, followed by an increase (10-15 $\mathrm{min}$ ) and then another down-regulation (30-60 min). There are conflicting findings on the role of AMPK activation on $\beta$ cell function (Fu et al. 2013). The fragment also significantly increased ERK phosphorylation within 5-15 $\mathrm{min}$, and this was followed by a decrease at later time points (30-60 min). It also induced a slightly delayed (15-30 min) and variable modulation of PKC phosphorylation. We did not detect modulation in the phosphorylation of AKT, PLC $\gamma$, PLA2, JNK, p38 (Supplementary Figure 4), or in the substrates of PKA or PKD (data not shown). Very similar effects were observed for the other insulinoma cell lines (Supplementary Figure 5).

TLQP-62-induced signaling pathways were further probed after exposure to specific inhibitors for $30 \mathrm{~min}$ before stimulation for $1 \mathrm{~h}$. The ERK inhibitor UO126 $(1 \mu \mathrm{M})$, the PKC inhibitor Go6983 $(1 \mu \mathrm{M})$, and the phospholipase inhibitor U73122 $(2 \mu \mathrm{M})$ did not affect TLQP-62-induced $(10 \mu \mathrm{M})$ insulin secretion (Table 1). This finding indicated that activated kinases were downstream from the calcium influx necessary for insulin secretion (see also the calcium mobilization section). In fact, the non-competitive inhibitor of sarco/endoplasmic reticulum $\mathrm{Ca}^{2+}$ ATPase thapsigargin $(500 \mu \mathrm{M})$, which was used to deplete intracellular ER calcium storage, significantly decreased constitutive and TLQP-62-induced insulin secretion (by about 40\%), which suggests the involvement of $\mathrm{Ca}^{2+}$ being released from intracellular storage (see also the next section). Indeed, thapsigargin did not decrease the release of TLQP-62 (Supplementary Figure 6), which suggests that there is a different secretory mechanism for cargo vesicles (Giordano et al. 2008).

Recently, C3aR1 was identified as the TLQP-21 receptor (Hannedouche et al. 2013). We therefore used the C3a peptide agonist C3a70-77 and the C3a receptor antagonist SB290157 to analyze whether this receptor

Published by Bioscientifica Ltd. 
was also involved in TLQP-62-mediated signaling events. We did not obtain inhibition of TLQP-62-induced insulin secretion activity in the presence of SB290157 (Supplementary Figure 7), which indicates that TLQP-62 and
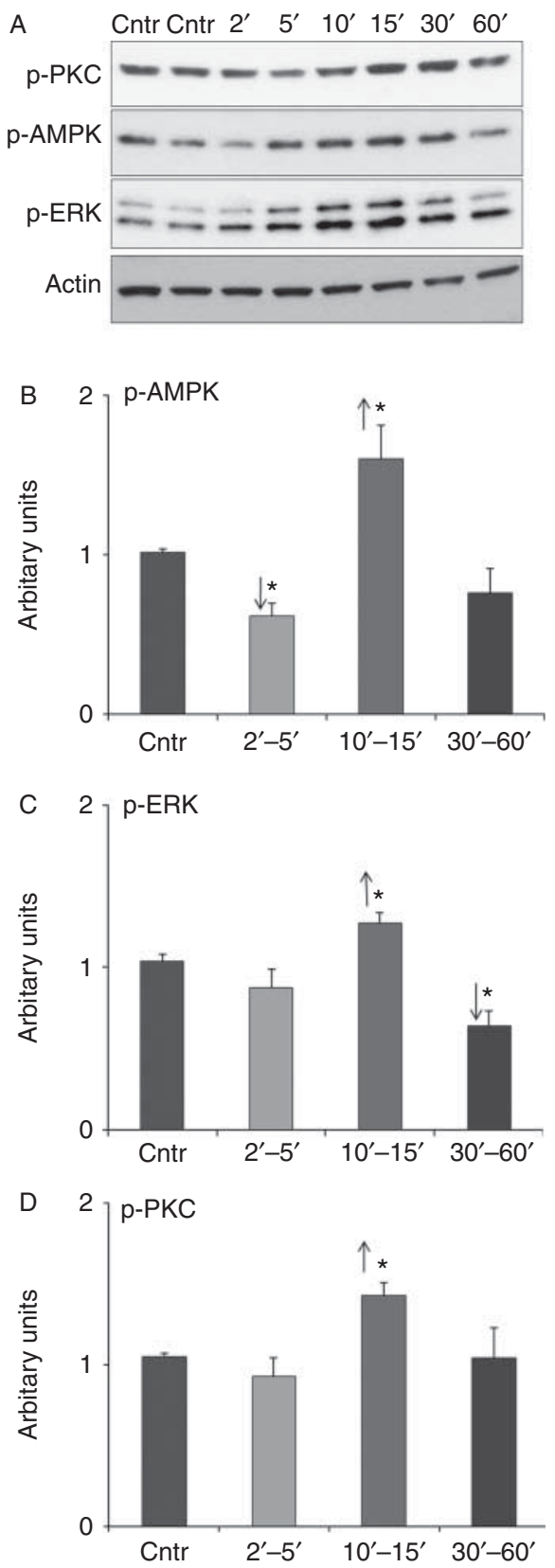

\section{Figure 4}

Early signaling of TLQP-62 in INS1E cells. (A) After $1 \mathrm{~h}$ of serum starvation, cells were exposed to $10 \mu \mathrm{M}$ TLQP-62 for different amounts of time and analyzed for phosphorylation of different kinases by western blotting. (B, $C$ and D) Semiquantitative densitometric analysis of individual phosphorylated activated kinases. Graphs of means \pm s.E.M. of five experiments, with data from the indicated time intervals grouped together. Statistically significant differences between values of treated cells and control cells (Cntr: 1, arbitrary units) were analyzed using the paired two-tailed $t$-test: ${ }^{*} P<0.05$.
Table 1 Insulin secretion in the INS1E cell line. Cells were pretreated with specific inhibitors for $30 \mathrm{~min}$ before stimulation with TLQP-62 $(10 \mu \mathrm{M})$ for $1 \mathrm{~h}$

\begin{tabular}{|c|c|c|}
\hline Inhibitor & TLQP-62 & $\begin{array}{l}\text { Insulin level } \\
\text { (arbitrary units) }\end{array}$ \\
\hline- & - & $1.0 \pm 0.1$ \\
\hline- & + & $3.8 \pm 0.5$ \\
\hline Go6983 & - & $1.0 \pm 0.3$ \\
\hline Go6983 & + & $4.0 \pm 0.6$ \\
\hline U73122 & - & $1.8 \pm 0.3$ \\
\hline U73122 & + & $3.8 \pm 0.4$ \\
\hline U0126 & - & $1.0 \pm 0.1$ \\
\hline U0126 & + & $3.5 \pm 0.3$ \\
\hline Thapsigargin & - & $0.6 \pm 0.1$ \\
\hline Thapsigargin & + & $2.3 \pm 0.4^{*}$ \\
\hline
\end{tabular}

${ }^{*} P<0.05$ vs respective no TLQP-62.

TLQP-21 ligate different receptors. This finding is in line with the recently identified mechanism of C3aR1 activation by TLQP-21 (Cero et al. 2014).

\section{TLQP-62 increases intracellular calcium mobilization in INS1E cells}

To further dissect the mechanism of action of TLQP62-mediated insulin release, we analyzed calcium influx $\left(\left[\mathrm{Ca}^{2+}\right]_{\mathrm{i}}\right)$ with a FURA-2 florescence assay. We found that TLQP-62 increased intracellular calcium to a degree that was comparable with that of the TPA stimulation and greater than that produced by Frsk or $\mathrm{KCl}$ (Fig. 5A).

As for insulin secretion, the dose-dependent activity of TLQP-62 on calcium mobilization produced a low, but detectable, calcium increase at $1 \mu \mathrm{M}$, which reached a plateau at 5-10 $\mu \mathrm{M}$ (Supplementary Figure 8). The recovery of physiological calcium concentrations was achieved a few minutes after stimulus (Supplementary Video 1). Calcium influx upon exposure to TLQP-62 was detected also in $\beta$ TC6 and MIN6B1 cell lines (Supplementary Figure 9).

Cells that had been depleted of glucose for $60 \mathrm{~min}$ before exposure to TLQP-62 had reduced calcium mobilization (Fig. 5B). When kept in high glucose (Fig. 5C), the basal intracellular calcium concentration was increased (compare the basal levels of the no-glucose condition in Fig. 5B with that in the high-glucose condition in Fig. 5C) and stimulation with TLQP-62 produced a normal response. However, calcium remained elevated after the stimulation (with a ratio higher than 1.5 ), which indicated a difficulty in extruding calcium from the cytosol.

Of note, Frsk produced a fast calcium influx that remained sustained (Fig. 5D) but had fluctuations in the

Published by Bioscientifica Ltd 

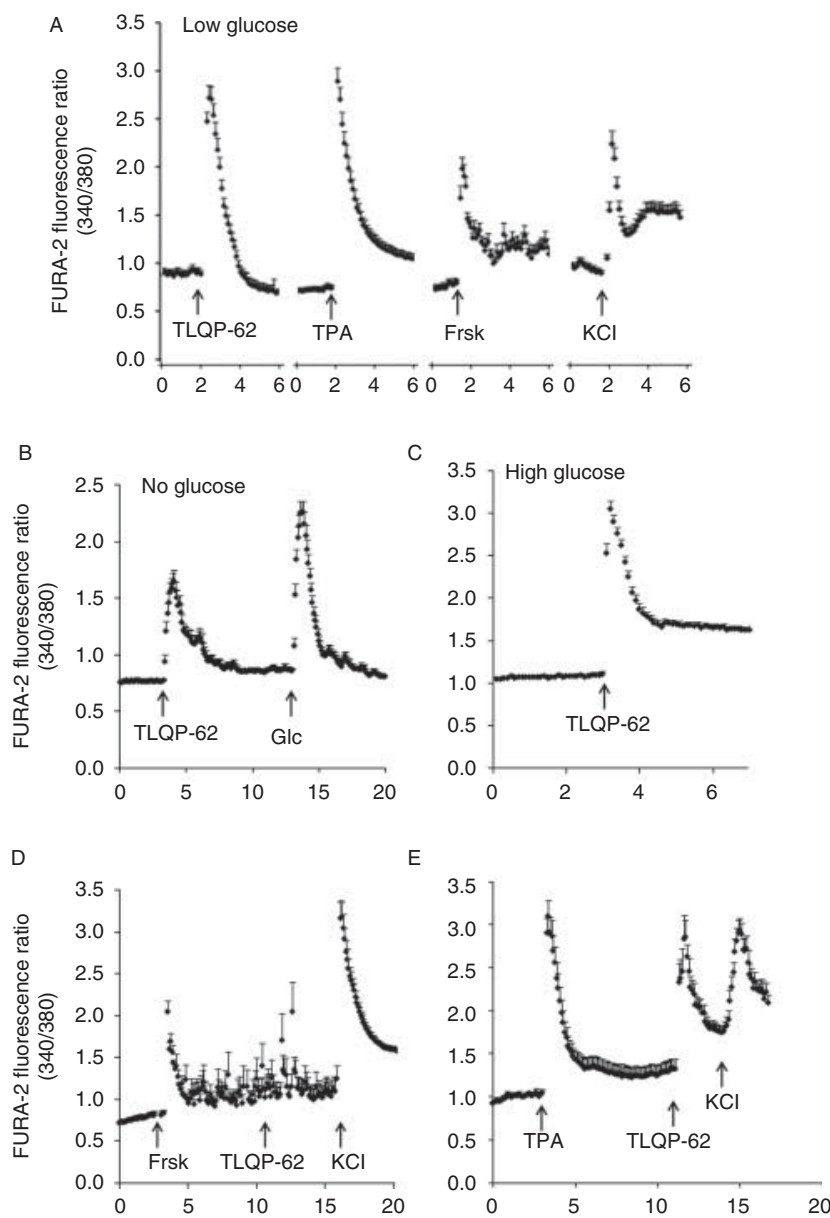

Figure 5

Calcium influx in INS1E cells. Comparison of cytoplasmic calcium levels measured with Fura2AM. (A) Signal after stimulation with $10 \mu \mathrm{M}$ TLQP-62, $100 \mathrm{nM}$ tetra phorbol myristate (TPA), $10 \mu \mathrm{M}$ forskolin (Frsk), or $56 \mathrm{mM} \mathrm{KCl}$, in $4.5 \mathrm{mM}$ glucose HBSS. (B) Glucose responsiveness. Cells were glucosestarved for $60 \mathrm{~min}$ before stimulation with $20 \mathrm{mM}$ glucose or $10 \mu \mathrm{M}$ TLQP62. (C) Effect of $10 \mu \mathrm{M}$ TLQP-62 on cells kept in $20 \mathrm{mM}$ glucose. (D) Pretreatment with $10 \mu \mathrm{M}$ Frsk desensitized the cells to TLQP-62-induced calcium influx but reinforced the effect of $56 \mathrm{mM} \mathrm{KCl}$. (E) In contrast, pretreatment with $100 \mathrm{nM}$ TPA had no effect on TLQP-62-induced calcium influx. The panels are of representative experiments and give the means \pm S.E.M. of 35-45 individual single-cell recordings.

single-cell traces (Supplementary Figure 10). TLQP-62's effect was strongly negatively affected by Frsk-induced PKA activation, which suggests down-regulation of its receptor (Fig. 5D). Conversely, stimulation of the PKC pathway with TPA did not affect TLQP-62-induced stimulation of calcium influx (Fig. 5E). However, both pathways seemed to stimulate the effect of high potassium on calcium influx: under the normal condition, the peak was around a 1.5:2 ratio (Fig. 5A), whereas the peak increased to 3.0 in the presence of Frsk or TPA (Fig. 5D and E).
Multiple applications of TLQP-62 did not decrease calcium stimulation, which suggests that the receptor did not become down-regulated or that there was a very fast recovery (Fig. 6A). Depletion of intracellular calcium by thapsigargin strongly decreased the peak calcium signal upon stimulation with TLQP-62 (Fig. 6B); this also occurred with $\mathrm{KCl}$, which opens voltage-dependent membrane channels and then activates ER calcium flux. Indeed, in the absence of a physiological extracellular calcium concentration (Fig. 6D), the activity of TLQP-62 was strongly decreased. Surprisingly, the absence of extracellular calcium weakly affected $\mathrm{KCl}$-induced calcium influx (Fig. 6C and D). We hypothesize that sustained, selfreinforcing calcium-induced calcium release (Lemmens et al. 2001) is involved in TLQP-62- and KCl-induced insulin secretion.

Together, these findings clearly demonstrate that in INS1E cells, TLQP-62 induces calcium influx via the opening of membrane calcium channels and by releasing it from internal storage.

\section{The trophic and proliferative effects of TLQP-62 on insulinoma cell lines}

INS1 cells were exposed for $24 \mathrm{~h}$ to different agents and assessed for mitochondrial activity with the MTT assay and DNA replication by assessment of BrdU incorporation.
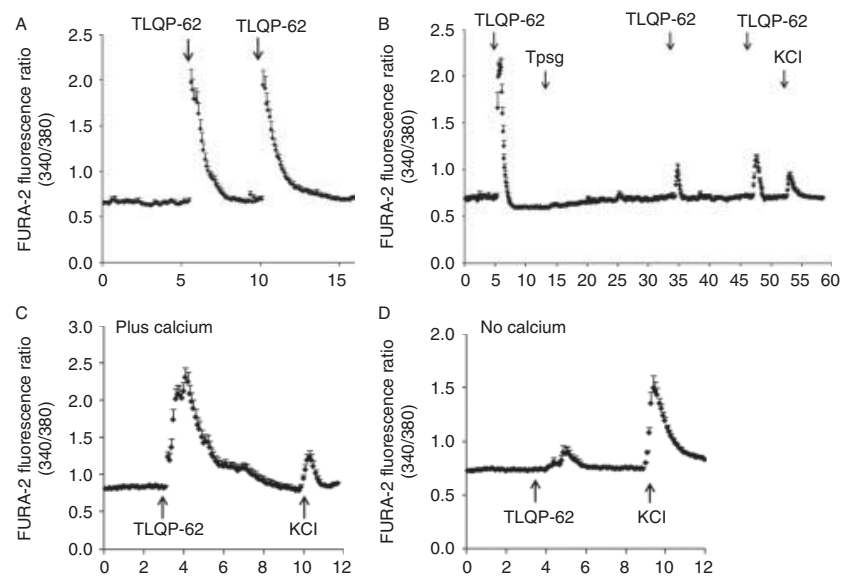

Figure 6

Intracellular storage and extracellular calcium influx in INS1E cells. (A) Multiple stimulations with $10 \mu \mathrm{M}$ TLQP-62 did not decrease calcium influx. (B) Pretreatment with $500 \mu \mathrm{M}$ thapsigargin (Tpsg) depleted intracellular calcium storage uptake, which reduced the response to $10 \mu \mathrm{M}$ TLQP-62 and then $56 \mathrm{mM} \mathrm{KCl} 20$ min later. (C) The effects of TLQP-62 and $\mathrm{KCl}$ in the presence of a physiological concentration of extracellular calcium in the HBSS medium. (D) The effects of TLQP-62 and $\mathrm{KCl}$ in the absence of extracellular calcium. The panels are of representative experiments and give the means \pm S.E.M. of $35-45$ single-cell recordings.

Published by Bioscientifica Ltd. 
TLQP-62 stimulated a small, but not statistically significant, increase of the signal in both assays (Supplementary Figure 11). Experiments performed on INS1E, $\beta$ TC6, and MIN61B cells produced similar results, as did a $48 \mathrm{~h}$ exposure (data not shown), which indicates that TLQP62 peptides do not significantly affect insulinoma cell viability.

\section{TLQP-62 improves glucose tolerance in vivo}

Finally, after having established the cell-autonomous effect of TLQP-62 as a novel insulin secretagogue in vitro, we aimed to translate the present findings in vivo by testing the hypothesis that TLQP-62 modulates glucose homeostasis in mice. The experiment was conducted in lean non-obese and non-diabetic WT mice.

To this end, mice were fasted overnight and glucose tolerance was investigated in the presence and absence of different doses of TLQP-62. We found that acute injection of TLQP-62 $(5 \mathrm{mg} / \mathrm{kg})$ significantly improved glucose tolerance in the glucose tolerance test (Fig. 7).

\section{Discussion}

Impaired insulin secretion and insulin resistance play major roles in the development of T2D. The presence of VGF peptides has been detected in $\beta$ cells as well as in other cell types of the islets of Langerhans (Possenti et al. 1999, Cocco et al. 2007, Stephens et al. 2012), which most likely suggests a paracrine or autocrine mechanism of action. These peptides are also produced from the neurons of the autonomic nervous system and pancreatic intra-mural ganglia (Cocco et al. 2007).
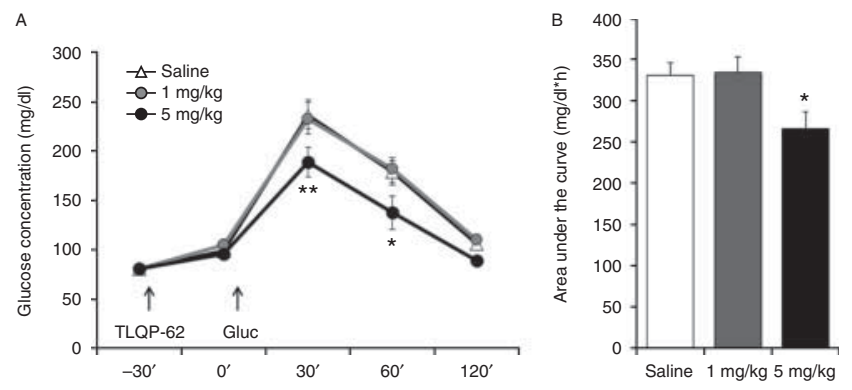

Figure 7

Glucose tolerance test in vivo. (A) Male CD1 mice weighing $\sim 30 \mathrm{~g}$ each were injected with a single dose of saline $(n=12), 1 \mathrm{mg} / \mathrm{kg}$ TLQP-62 $(n=8)$, or $5 \mathrm{mg} / \mathrm{kg}$ TLQP-62 $(n=11)$. Acute injection of TLQP-62 significantly improved glucose tolerance in mice only at the higher dose. (B) Area under the curve of glucose concentration during the GTT. $* P<0.05$ and $* * P<0.01$.

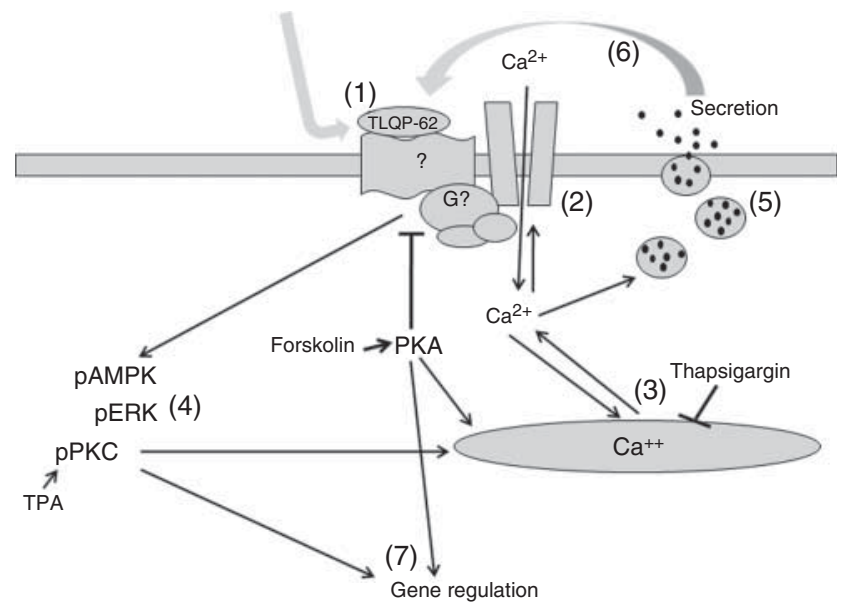

\section{Figure 8}

Proposed model of TLQP-62's mechanism of action. Released TLQP-62 ligates a yet-to-be-identified receptor (1), activating signal transduction cascades by first opening calcium channels on the membrane (2) and stimulating endoplasmic reticulum release (3), and then secondarily modulating the AMPK, PKC, and ERK pathways (4). The resulting increase in intracellular $\mathrm{Ca}^{2+}$ concentration is permissive for the secretion of insulin (5). TLQP-62 is released along with insulin and exerts a paracrine effect (6). TLQP-62 also has an effect on gene transcription (7).

The secretory granules of $\beta$ cells contain a diverse cargo of peptides and other biologically active molecules. Thus, stimuli that cause the secretion of insulin also cause the release of these molecules, which may interfere positively or negatively in an autocrine manner (Suckale \& Solimena 2010). Because VGF-derived C-terminal peptides have been found to be preferentially produced by $\beta$ cells (Possenti et al. 1999), we tested their capacity to stimulate insulin secretion. Among the C-terminal VGFderived peptides analyzed, we found that the TLQP-62 fragment caused strong induction of insulin secretion in vitro in the presence of low glucose. This stimulatory effect was dose dependent, and it potentiated GSIS. TLQP62 also quickly increased intracellular calcium mobilization, an event dependent on calcium influx from the extracellular compartment as well as from intracellular storage (Lemmens et al. 2001). The action of TLQP-62 required the presence of a physiological glucose level $(4.5 \mathrm{mM})$, because calcium influx was decreased in glucose-free medium. Among the other analyzed VGFpeptides, TLQP-21 - as reported previously (Stephens et al. 2012) - did not strongly increase insulin release under the low-glucose condition but did produce a positive effect on GSIS in the INS1E cell line. Regarding the other C-terminal-derived peptides, AQEE-30 and LQEQ-19 but not YIEH-10 still maintained an ability to stimulate

Published by Bioscientifica Ltd 
insulin secretion, but they were less potent than the fulllength C-terminal TLQP-62 peptide.

The receptor(s) for these peptides has(have) not yet been identified. Recently, TLQP-21 has been reported to bind to the C3a receptor (Hannedouche et al. 2013, Cero et al. 2014). C3aR1 can be activated by C3a and TLQP-21 with an intact C-terminal Ala-Arg moiety, which is absent in TLQP-62. Moreover, the C3aR1 antagonist SB290157 did not inhibit the pro-secretory effect of TLQP-62. Accordingly, we hypothesize that TLQP-62 activates a different receptor, but we do not exclude that AQEE-30 and LQEQ-19, which still retain some biological activity, could also be active on that receptor. It seems that the most C-terminal portion of the peptide is responsible for receptor binding, but more structural and pharmacological studies are required to determine this conclusively.

Intracellular signaling activated by TLQP-62 was fast (within 2-5 min) and produced reversible dephosphorylation of AMPK followed by phosphorylation of ERK and PKC. The involvement of AMPK in insulin secretion has been intensively discussed, but discrepancy among different papers exists. The present finding is similar to that of Fu et al. (2013): a fast down-regulation of p-AMPK mimics the effect of high intracellular ATP by inducing the cell to secrete insulin and by closing the potassium channels. We did not see activation of PKA-substrate phosphorylation by TLQP-62. Of note, Frsk - which activates the PKA pathwayblunted the fast effect of TLQP-62 on calcium. Conversely, TPA - which activates and then down-regulates PKC - did not inhibit TLQP-62-induced calcium mobilization.

We also assessed gene expression induced by high glucose, exposure to TLQP-62, and PKA activation (via Frsk). Slight increases in Ins 1 and $V g f$ - but not Ins 2 - genes were produced by high glucose and were statistically significant only early on (at $2 \mathrm{~h}$ ). TLQP-62 was also able to stimulate Ins1 and $V g f$ at this early time point, with weak Ins1 up-regulation also occurring after $18 \mathrm{~h}$ of exposure. In contrast, Frsk induced a strong up-regulation of $V g f$ overnight. There was no synergistic effect with high glucose at any time point, which suggests a probable glucose transitory effect resulting from the replacement of intragranular protein storage after the secretory stimulus. This hypothesized exchange of secreted proteins is supported by the increase in VGF-protein precursor that occurs early after exposure to high glucose. Because cyclohexamide blocked accumulation of VGF-protein precursor, we assume that this effect is regulated at the transcriptional level.

It has been previously reported that TLQP-21 causes a protective and trophic effect on islet $\beta$ cells (Stephens et al.
2012). In the present cell culture conditions, we detected a slight increase in cell trophism and proliferation after a $24 \mathrm{~h}$ stimulation with TLQP-62, but these data were not statistically significant.

After finding that TLQP-62 is a potent insulin secretagogue in vitro, we tested its effect on glucose tolerance in vivo. We found that administration of TLQP62 improved glucose tolerance in mice, which suggests that the peptide exerts an insulin secretagogue effect in vivo as well. The significant improvement of glucose tolerance was particularly evident at the $30 \mathrm{~min}$ time point, which is suggestive of enhanced insulin secretion. Insulin levels were not directly determined in the present experiment; therefore, further studies are needed to support this conclusion.

Therefore, we propose a model in which TLQP-62 induces a fast increase in intracellular calcium mobilization via its release from intracellular storage and membrane calcium channel opening, and these two effects are self-reinforcing (Fig. 8). A secondary event involves the activation of kinases such as PKA that could regulate gene transcription and be responsible for downregulation of the TLQP-62 signal. Moreover, the secretion of VGF-derived peptides by $\beta$ cells could have a selfreinforcing paracrine effect on insulin secretion. We conclude that TLQP-62 is a new insulin secretagogue that improves glucose tolerance and could thus be considered a new target for drug discovery programs aimed at treating conditions characterized by impaired insulin secretion, such as T1D and the late phase of T2D.

\section{Supplementary data}

This is linked to the online version of the paper at http://dx.doi.org/10.1530/ JME-14-0313.

\section{Declaration of interest}

The authors declare that there is no conflict of interest that could be perceived as prejudicing the impartiality of the research reported.

\section{Funding}

The work was supported in part by a Minnesota Partnership for Biotechnology and Medical Genomics' Decade of Discovery in Diabetes grant (to A B) and by MIUR (to R P).

\section{Acknowledgements}

We thank Dr $\mathrm{P}$ Halban for productive discussion and for providing the MIN6B1 cell line. We also thank Pierre Maeclher for providing us with the INS1E cell line.

Published by Bioscientifica Ltd. 


\section{References}

Alder J, Thakker-Varia S, Bangasser DA, Kuroiwa M, Plummer MR, Shors TJ \& Black IB 2003 Brain-derived neurotrophic factor-induced gene expression reveals novel actions of VGF in hippocampal synaptic plasticity. Journal of Neuroscience 23 10800-10808.

Bartolomucci A, La Corte G, Possenti R, Locatelli V, Rigamonti AE, Torsello A, Bresciani E, Bulgarelli I, Rizzi R, Pavone F et al. 2006 TLQP21, a VGF-derived peptide, increases energy expenditure and prevents the early phase of diet-induced obesity. PNAS 103 14584-14589. (doi:10.1073/pnas.0606102103)

Bartolomucci A, Bresciani E, Bulgarelli I, Rigamonti AE, Pascucci T, Levi A, Possenti R, Torsello A, Locatelli V, Muller EE et al. 2009 Chronic intracerebroventricular injection of TLQP-21 prevents high fat diet induced weight gain in fast weight-gaining mice. Genes \& Nutrition 4 49-57. (doi:10.1007/s12263-009-0110-0)

Bartolomucci A, Possenti R, Mahata SK, Fischer-Colbrie R, Loh YP \& Salton SR 2011 The extended granin family: structure, function, and biomedical implications. Endocrinology Review 32 755-797. (doi:10.1210/er.2010-0027)

Bozdagi O, Rich E, Tronel S, Sadahiro M, Patterson K, Shapiro ML, Alberini CM, Huntley GW \& Salton SR 2008 The neurotrophininducible gene Vgf regulates hippocampal function and behavior through a brain-derived neurotrophic factor-dependent mechanism. Journal of Neuroscience 28 9857-9869. (doi:10.1523/JNEUROSCI. 3145-08.2008)

Braun M, Ramracheya R \& Rorsman P 2012 Autocrine regulation of insulin secretion. Diabetes, Obesity \& Metabolism 14 143-151. (doi:10.1111/ j.1463-1326.2012.01642.x)

Cero C, Vostrikov V, Verardi R, Severini C, Gopinath T, Braun PD, Sassano MF, Gurney A, Roth BL, Vulchanova L et al. 2014 The TLQP-21 peptide activates the G-protein-coupled receptor C3aR1 via a foldingupon-binding mechanism. Structure 22 1744-1753. (doi:10.1016/j.str. 2014.10.001)

Cocco C, Brancia C, Pirisi I, D’Amato F, Noli B, Possenti R \& Ferri GL 2007 VGF metabolic-related gene: distribution of its derived peptides in mammalian pancreatic islets. Journal of Histochemistry and Cytochemistry 55 619-628. (doi:10.1369/jhc.6A7040.2007)

Efrat S, Linde S, Kofod H, Spector D, Delannoy M, Grant S, Hanahan D \& Baekkeskov S $1988 \beta$-cell lines derived from transgenic mice expressing a hybrid insulin gene-oncogene. PNAS 85 9037-9041. (doi:10.1073/ pnas.85.23.9037)

Fargali S, Scherer T, Shin AC, Sadahiro M, Buettner C \& Salton SR 2012 Germline ablation of VGF increases lipolysis in white adipose tissue. Journal of Endocrinology 215 313-322. (doi:10.1530/JOE-12-0172)

Ferri GL, Noli B, Brancia C, D'Amato F \& Cocco C 2011 VGF: an inducible gene product, precursor of a diverse array of neuro-endocrine peptides and tissue-specific disease biomarkers. Journal of Chemical Neuroanatomy 42 249-261. (doi:10.1016/j.jchemneu.2011.05.007)

Fu A, Eberhard CE \& Screaton RA 2013 Role of AMPK in pancreatic $\beta$ cell function. Molecular and Cellular Endocrinology 366 127-134. (doi:10.1016/j.mce.2012.06.020)

Giordano T, Brigatti C, Podini B, Bonifacio E, Melodesi J \& Malosio ML $2008 \beta$ cell chromogranin B is partially segregated in distinct granules and can be released separately from insulin in response to stimulation. Diabetologia 51 997-1007. (doi:10.1007/s00125-008-0980-5)

Hahm S, Mizuno TM, Wu TJ, Wisor JP, Priest CA, Kozak CA, Boozer CN, Peng B, McEvoy RC \& Good P 1999 Targeted deletion of the Vgf gene indicates that the encoded secretory peptide precursor plays a novel role in the regulation of energy balance. Neuron 23 537-548. (doi:10.1016/S0896-6273(00)80806-5)

Hahm S, Fekete C, Mizuno TM, Windsor J, Yan H, Boozer CN, Lee C, Elmquist JK, Lechan RM, Mobbs CV et al. 2002 VGF is required for obesity induced by diet, gold thioglucose treatment, and agouti and is differentially regulated in pro-opiomelanocortin- and neuropeptide
Y-containing arcuate neurons in response to fasting. Journal of Neuroscience 22 6929-6938.

Hannedouche S, Beck V, Leighton-Davies J, Beibel M, Roma G, Oakeley EJ, Lannoy V, Bernard J, Hamon J, Barbieri S et al. 2013 Identification of the C3a receptor (C3AR1) as the target of the VGF-derived peptide TLQP-21 in rodent cells. Journal of Biological Chemistry 288 27434-27443. (doi:10.1074/jbc.M113.497214)

Helle KB 2004 The granin family of uniquely acidic proteins of the diffuse neuroendocrine system: comparative and functional aspects. Biological Reviews of the Cambridge Philosophical Society 79 769-794. (doi:10.1017/ S146479310400644X)

Hohmeier HE, Mulder H, Chen G, Henkel-Rieger R, Prentki M \& Newgard CB 2000 Isolation of INS-1-derived cell lines with robust ATP-sensitive $\mathrm{K}+$ channel-dependent and -independent glucosestimulated insulin secretion. Diabetes 49 424-430. (doi:10.2337/ diabetes.49.3.424)

Jones PM \& Persaud SJ 1998 Protein kinases, protein phosphorylation, and the regulation of insulin secretion from pancreatic $\beta$-cells. Endocrine Reviews 19 429-461. (doi:10.1210/edrv.19.4.0339)

Lemmens R, Larsson O, Berggren PO \& Islam MS $2001 \mathrm{Ca}^{2+}$-induced $\mathrm{Ca}^{2+}$ release from the endoplasmic reticulum amplifies the $\mathrm{Ca}^{2+}$ signal mediated by activation of voltage-gated L-type $\mathrm{Ca}^{2+}$ channels in pancreatic $\beta$-cells. Journal of Biological Chemistry 276 9971-9977. (doi:10.1074/jbc.M009463200)

Levi A, Eldridge JD \& Paterson BM 1985 Molecular cloning of a gene sequence regulated by nerve growth factor. Science 229 393-395. (doi:10.1126/science.3839317)

Lilla V, Webb G, Rickenbach K, Maturana A, Steiner DF, Halban PA \& Irminger JC 2003 Differential gene expression in well-regulated and dysregulated pancreatic $\beta$-cell (MIN6) sublines. Endocrinology 144 1368-1379. (doi:10.1210/en.2002-220916)

Melloul D, Marshak S \& Cerasi E 2002 Regulation of Insulin gene transcription. Diabetologia 45 309-326. (doi:10.1007/s00125-0010728-y)

Miyazaki J, Araki K, Yamato E, Ikegami H, Asano T, Shibasaki Y, Oka Y \& Yamamura K 1990 Establishment of a pancreatic $\beta$ cell line that retains glucose-inducible insulin secretion: special reference to expression of glucose transporter isoforms. Endocrinology 127 126-132. (doi:10.1210/ endo-127-1-126)

Moin AS, Yamaguchi H, Rhee M, Kim JW, Toshinai K, Waise TM, Naznin F, Matsuo T, Sasaki K, Minamino N et al. 2012 Neuroendocrine regulatory peptide-2 stimulates glucose-induced insulin secretion in vivo and in vitro. Biochemical and Biophysical Research Communications $\mathbf{4 2 8}$ 512-517. (doi:10.1016/j.bbrc.2012.10.073)

Petrocchi P, Quaresima S, Mongiardi MP, Severini C \& Possenti R 2010 Activation of kinase phosphorylation by heat-shift and mild heatshock. Cell Biology International Reports 17 e00002. (doi:10.1042/ CBR20100002)

Petrocchi Passeri P, Biondini L, Mongiardi MP, Mordini N, Quaresima S, Frank C, Baratta M, Bartolomucci A, Levi A \& Severini C 2013 Neuropeptide TLQP-21, a VGF internal fragment, modulates hormonal gene expression and secretion in GH3 cell line. Neuroendocrinology 97 212-224. (doi:10.1159/000339855)

Philippe J \& Missotten M 1990 Functional characterization of a cAMP-responsive element of the rat insulin I gene. Journal of Biological Chemistry 265 1465-1469.

Possenti R, Eldridge JD, Paterson BM, Grasso A \& Levi A 1989 A protein induced by NGF in PC12 cells is stored in secretory vesicles and released through the regulated pathway. ЕMBO Journal 8 2217-2223.

Possenti R, Rinaldi AM, Ferri GL, Borboni P, Trani E \& Levi A 1999 Expression, processing, and secretion of the neuroendocrine VGF peptides by INS-1 cells. Endocrinology 140 3727-3735. (doi:10.1210/ endo.140.8.6920)

Possenti R, Muccioli G, Petrocchi P, Cero C, Cabassi A, Vulchanova L, Riedl MS, Manieri M, Frontini A, Giordano A et al. 2012 Characterization of a novel peripheral pro-lipolytic mechanism in mice: role of VGF-derived 
peptide TLQP-21. Biochemical Journal 441 511-522. (doi:10.1042/ BJ20111165)

Rubí B, Antinozzi PA, Herrero L, Ishihara H, Asins G, Serra D, Wollheim CB, Maechler P \& Hegardt FG 2002 Adenovirus-mediated overexpression of liver carnitine palmitoyltransferase I in INS1E cells: effects on cell metabolism and insulin secretion. Biochemical Journal 364 219-226.

Salton SR, Fischberg DJ \& Dong KW 1991 Structure of the gene encoding VGF, a nervous system-specific mRNA that is rapidly and selectively induced by nerve growth factor in PC12 cells. Molecular and Cellular Biology 11 2335-2349. (doi:10.1128/MCB.11.5.2335)

Severini C, La Corte G, Improta G, Broccardo M, Agostini S, Petrella C, Sibilia V, Pagani F, Guidobono F, Bulgarelli I et al. 2009 In vitro and in vivo pharmacological role of TLQP-21, a VGF-derived peptide, in the regulation of rat gastric motor functions. British Journal of Pharmacology 157 984-993. (doi:10.1111/j.1476-5381.2009.00192.x)

Stephens SB, Schisler JC, Hohmeier HE, An J, Sun AY, Pitt GS \& Newgard CB 2012 A VGF-derived peptide attenuates development of type 2 diabetes via enhancement of islet $\beta$-cell survival and function. Cell Metabolism 16 33-43. (doi:10.1016/j.cmet.2012.05.011)

Suckale J \& Solimena M 2010 The insulin secretory granule as a signaling hub. Trends in Endocrinology and Metabolism 21 599-609. (doi:10.1016/j. tem.2010.06.003)
Thakker-Varia S, Behnke J, Doobin D, Dalal V, Thakkar K, Khadim F, Wilson E, Palmieri A, Antila H, Rantamaki T et al. 2014 VGF (TLQP-62)induced neurogenesis targets early phase neural progenitor cells in the adult hippocampus and requires glutamate and BDNF signaling. Stem Cell Research 12 762-777. (doi:10.1016/j.scr.2014.03.005)

Trani E, Ciotti T, Rinaldi AM, Canu N, Ferri GL, Levi A \& Possenti R 1995 Tissue-specific processing of the neuroendocrine protein VGF. Journal of Neurochemistry 65 2441-2449. (doi:10.1046/j.1471-4159.1995. 65062441.x)

Trani E, Giorgi A, Canu N, Amadoro G, Rinaldi AM, Halban PA, Ferri GL, Possenti R, Schininà ME \& Levi A 2002 Isolation and characterization of VGF peptides in rat brain. Role of PC1/3 and PC2 in the maturation of VGF precursor. Journal of Neurochemistry 81 565-574. (doi:10.1046/ j.1471-4159.2002.00842.x)

Watson E, Hahm S, Mizuno TM, Windsor J, Montgomery C, Scherer PE, Mobbs CV \& Salton SR 2005 VGF ablation blocks the development of hyperinsulinemia and hyperglycemia in several mouse models of obesity. Endocrinology 146 5151-5163. (doi:10.1210/en.2005-0588)

Watson E, Fargali S, Okamoto H, Sadahiro M, Gordon RE, Chakraborty T, Sleeman MW \& Salton SR 2009 Analysis of knockout mice suggests a role for VGF in the control of fat storage and energy expenditure. BMC Physiology 28 9-19. (doi:10.1186/1472-6793-9-19)

Received in final form 20 March 2015

Accepted 9 April 2015
(C) 2015 Society for Endocrinology Printed in Great Britain
Published by Bioscientifica Ltd. 